\title{
The Role of a Bacterial Siderophore and of Iron in the Germination and Appressorium Formation by Conidia of Colletotrichum acutatum
}

\author{
By SIMON J. SLADE, ' TERENCE R. SWINBURNE ${ }^{1}$ AND \\ SIMON A. ARCHER ${ }^{2 *}$ \\ 'East Malling Research Station, Maidstone, Kent ME19 6BJ, UK \\ ${ }^{2}$ Pure and Applied Biology Department, Imperial College, South Kensington, London, UK
}

(Received 16 May 1985)

\begin{abstract}
Pseudomonas sp. isolate UV3, when added to conidial suspensions of Colletotrichum acutatum, stimulated germination and appressorium formation on glass slides and on host surfaces. A siderophore $\left(\mathrm{S}_{\mathrm{A}}\right)$, purified from low-iron culture of the bacteria, stimulated germination and appressorium formation to a significantly greater extent than the bacterial cells alone. The fully chelated siderophore $\left(\mathrm{S}_{\mathrm{A}} \mathrm{Fe}\right)$ and free ferric iron were inhibitory in vitro to germination and appressorium formation but inhibited only the latter in vivo. The $\mathrm{S}_{\mathrm{A}}$ is compared with nutrients at similar concentrations, and the role of the phytoplane microflora and associated siderophores is discussed in relation to fungal infection.
\end{abstract}

\section{INTRODUCTION}

The formation of an appressorium, a cushion-like structure from which the infection peg develops, is a prerequisite for infection by many plant pathogenic fungi. Species of Colletotrichum produce both light- and dark-pigmented appressoria, the latter being resistant structures with an innate dormancy.

Blakeman \& Parbery (1977) demonstrated that appressorium formation by Colletotrichum acutatum, an anthracnose pathogen of strawberry, was greatly enhanced by the presence of washed cells of Pseudomonas spp. in the inoculum drop. They attributed this phenomenon to nutrient competition, implicating in particular competition for amino acids. Blakeman \& Brodie (1977), Blakeman \& Parbery (1977) and Brodie \& Blakeman (1976) concluded that appressoria were formed in response to nutrient stress and drew an analogy with resting structures such as chlamydospores. Although nutrient competition from phylloplane microflora is almost certainly an important factor, other modes of action may be involved in the stimulation of fungal germination and appressorium formation, notably iron chelation.

Conidia of Colletotrichum musae do not germinate freely in water but do so readily in washings from banana fruit. This was ascribed to the presence in such washings of anthranilic acid (Swinburne, 1976). It was later shown that anthranilic acid is readily converted to 2,3dihydroxybenzoic acid (DHBA) and that this was the primary stimulant. The mode of action of DHBA appeared to be related to its iron-chelating properties. McCracken \& Swinburne (1979), using the same isolate of Pseudomonas sp. as Blakeman \& Parbery (1977), showed that a siderophore produced in iron-deficient medium by this isolate (UV3) was highly stimulatory to both germination and appressorium formation in C. musae. Such siderophores stimulate plant infection processes as a whole in C. musae (Brown \& Swinburne, 1981), Glomerella cingulata (Adikaram et al., 1982) and Botrytis cinerea (Brown \& Swinburne, 1982).

The aim of this study was to determine if bacterial siderophores could account for the previously observed stimulation of $C$. acutatum by Pseudomonas sp. isolate UV3. 


\section{METHODS}

Culture, maintenance and preparation of spore suspensions. Colletotrichum acutatum Simmonds was isolated from black-rot symptoms on strawberry fruit, cv. Brighton, which had been grown at East Malling Research Station from runners imported from the USA. The fungus was cultured on modified Cook's no. 2 medium (Swinburne, 1976) at $18^{\circ} \mathrm{C}$ under continuous illumination by fluorescent light. Conidial suspensions were prepared in sterile distilled water by removing slime spores from 14-1-old cultures with a sterile loop. They were washed three times by centrifugation and resuspension in sterile disti led water, and diluted to give a final concentration of $10^{5} \mathrm{ml}^{-1}$, for use in germination assays.

Pseudomonas sp. isolate UV3 was maintained on King's B medium (King et al., 1954) at $18{ }^{\circ} \mathrm{C}$ under constant illumination. Suspensions of bacteria from the edge of a 3-d-old colony were prepared in sterile distilled water. These were washed by centrifugation and resuspension in sterile distilled water three times and diluted to a concentration of $10^{7}$ bacteria $\mathrm{m}^{-1}$, for fungal germination assays.

Preparation of low-iron water and glassware. Warer used for washing glassware and preparation of test solutions was double glass-distilled and treated by passage down an ion-exchange resin column $\left(4 \times 25 \mathrm{~cm} \mathrm{Chelex} 100, \mathrm{Na}^{+}\right.$ form, 200-400 mesh, BioRad) to remove all traces of contaminating iron. Glassware for all experiments was soaked in $6 \mathrm{M}-\mathrm{HCl}$ overnight, rinsed in water and then soaked in $1 \mathrm{M}-\mathrm{NaOH}$ for $2 \mathrm{~h}$ before a final rinse in water. Low-iron glass microscope slides were stored under Analar ethanol.

Siderophore production. Siderophores were separated from culture filtrates after growth of the bacteria in a lowiron mineral salts/glucose medium as previously described (McCracken \& Swinburne, 1979). UV absorption spectra of a component, designated $\mathrm{S}_{\mathrm{A}}$, were recorded with increasing concentrations of added iron and over a $\mathrm{pH}$ range of 4 to 9 . The absorbance maximum of the rnajor peak was $\mathrm{pH}$ dependent $(398 \mathrm{~nm}$ at $\mathrm{pH} 7)$ and addition of iron directly increased absorbance at $450 \mathrm{~nm}$. This suggested that $S_{A}$ was a member of the pseudobactin (Teintze et al., 1981; Teintze \& Leong, 1981) and pyoverdine (Meyer \& Hornsperger, 1978; Meyer \& Abdallah, 1978) family of siderophores produced by Pseudomonas species. Fully chelated $\mathrm{S}_{\mathrm{A}}\left(\mathrm{S}_{\mathrm{A}} \mathrm{Fe}\right)$ was prepared by titration with $1 \mathrm{M}-\mathrm{Fe}_{2}\left(\mathrm{SO}_{4}\right)_{3}$ in a spectrophotometer cuvette urtil the absorbance at $450 \mathrm{~nm}$ did not rise further. This brown complex contained approximately equimolar $\mathrm{S}_{\mathrm{A}}$ and $\mathrm{Fe}^{3+}$, with no excess iron, and had lost most of the bright yellow-green fluorescence of the $S_{A}$. Neither the molecular weight nor the molar absorption coefficient of $S_{A}$ was accurately determined. It was assumed they were close to the figures given for pseudobactin as values for all the siderophores in the group are similar. $S_{A}$ and $S_{A} F$ concentrations, calculated by using the extinction coefficient of pseudobactin (Teintze $e t$ al., 1981), were adjusted to $10^{-4} \mathrm{M}$ and stored at $-18^{\circ} \mathrm{C}$.

Spore germination assays. Germination was assayed on glass slides, with $10 \mu 1$ droplets containing $5 \times 10^{3}$ conidia suspended in test solutions, water, or the bacterial suspension. Spores in at least five fields of view were counted in 12 replicate drops per treatment after $18 \mathrm{~h}$ incubation at $18^{\circ} \mathrm{C}$ in a humid chamber.

Stolons from healthy, mature plants of field-grown strawberry cv. Cambridge Favourite, were removed and cut into $10 \mathrm{~cm}$ lengths and suspended within a humid chamber. These were inoculated with $10 \mu \mathrm{l}$ drops of conidial suspensions, one or more per piece of stolon. Germination and appressorium formation were assessed by examining thin longitudinal sections of stolons stained with cotton blue in lactophenol (BDH) under a light microscope. Experiments were repeated at least once and counts of at least -300 conidia per treatment were analysed statistically.

\section{RESULTS AND DISCUSSION}

\section{Germination and appressorium formation by C. acutatum conidia in vitro}

The germination of $C$. acutatum conidia in distilled water ranged between $14 \%$ and $26 \%$, with a mean value \pm SE of $19 \pm 3 \%$. In $5 \times 10^{-5} \mathrm{M}-\mathrm{S}_{\mathrm{A}}$ germination ranged from $37 \%$ to $93 \%$, with a mean value of $60 \pm 17 \%$. Although the $S_{A}$ was always stimulatory, the extent of the stimulation was variable. This was not easily explained and may have been due to small differences in spore age and absolute slide cleanliness between the experiments. Certain conidial characteristics may favour the action of $S_{A}$, although there was no evidence to suggest what these may be as all experiments were done under the same specified conditions. The presence of live Pseudomonas sp. isolate UV3 stimulated germination but only by half as much as by $S_{A}$ (Table 1). This differs from previous results in which bacteria marginally inhibited germination (Blakeman \& Parbery, 1977). Appressorium production was stimulated in a manner similar to that described earlier except that dark (mature) appressoria were not produced on glass in that study. This may have been partly due to the particularly clean glass surfaces used during the present investigation, since it was noted that fewer appressoria were formed on new slides than on those that had been acid-washed. The percentage of germinated conidia that produced appressoria was not 
Table 1. Effect of $S_{A}$ and Pseudomonas UV3 on the germination and appressorium formation of C. acutatum conidia on glass slides

\begin{tabular}{|c|c|c|c|c|c|}
\hline \multirow[b]{2}{*}{ Treatment } & \multicolumn{3}{|c|}{ The results are means $\pm \mathrm{SE}$} & \multirow[b]{2}{*}{$\begin{array}{l}\text { Percentage of } \\
\text { germinated } \\
\text { conidia with } \\
\text { dark appressoria }\end{array}$} & \multirow[b]{2}{*}{$\begin{array}{c}\text { Percentage of } \\
\text { all conidia } \\
\text { with dark } \\
\text { appressoria }\end{array}$} \\
\hline & $\begin{array}{l}\text { Percentage } \\
\text { germination }\end{array}$ & $\begin{array}{l}\text { Percentage of } \\
\text { germinated } \\
\text { conidia with } \\
\text { appressoria }\end{array}$ & $\begin{array}{l}\text { Percentage of } \\
\text { all conidia } \\
\text { with } \\
\text { appressoria }\end{array}$ & & \\
\hline Control $\left(\mathrm{H}_{2} \mathrm{O}\right)$ & $14 \pm 5$ & $55 \pm 21$ & $9 \pm 4$ & $35 \pm 18$ & $7 \pm 4$ \\
\hline $5 \times 10^{-5} \mathrm{M}-\mathrm{S}_{\mathrm{A}}$ & $93 \pm 3$ & $97 \pm 2$ & $91 \pm 3$ & $56 \pm 11$ & $53 \pm 11$ \\
\hline $\begin{array}{l}\text { Pseudomonas UV3 } \\
\left(10^{7} \text { cells } \mathrm{ml}^{-1}\right)\end{array}$ & $47 \pm 11$ & $99 \pm 1$ & $46 \pm 10$ & $95 \pm 4$ & $42 \pm 8$ \\
\hline
\end{tabular}

Table 2. Effect of $S_{A}, S_{A} F e$ and $\mathrm{Fe}^{3+}$ on the germination and appressorium formation of C. acutatum conidia on glass slides

The results are means $\pm \mathrm{SE}$.

$\begin{array}{lcccc}\text { Treatment } & \begin{array}{c}\text { Percentage of } \\ \text { germinated } \\ \text { conidia with } \\ \text { appressoria }\end{array} & \begin{array}{c}\text { Percentage of } \\ \text { all conidia } \\ \text { with } \\ \text { appressoria }\end{array} & \begin{array}{c}\text { Percentage of } \\ \text { all conidia } \\ \text { with dark } \\ \text { appressoria }\end{array} \\ \text { Control }\left(\mathrm{H}_{2} \mathrm{O}\right) & 26 \pm 2 & 47 \pm 7 & 10 \pm 2 & 6 \pm 1 \\ \mathrm{~S}_{\mathrm{S}} & 51 \pm 3 & 68 \pm 4 & 35 \pm 3 & 18 \pm 2 \\ \mathrm{~S}_{\mathrm{A}} \mathrm{Fe} & 11 \pm 2 & 5 \pm 3 & 1 \pm 1 & < \pm 1 \\ \mathrm{Fe}_{2}\left(\mathrm{SO}_{+}\right)_{3} & 13 \pm 2 & 34 \pm 7 & 5 \pm 1 & 3 \pm 1 \\ & * & \text { All at a concentration of } 5 \times 10^{-5} \mathrm{M} .\end{array}$

Table 3. Effect of $S_{A}$, glucose, glutamine and alanine on germination and appressorium formation by $C$. acutatum conidia on glass slides

The results are means $\pm \mathrm{SE}$.

$\begin{array}{lccc}\text { Treatment* } & \begin{array}{c}\text { Percentage } \\ \text { germination }\end{array} & \begin{array}{c}\text { Percentage of } \\ \text { all conidia } \\ \text { with appressoria }\end{array} & \begin{array}{c}\text { Percentage of } \\ \text { all conidia with } \\ \text { dark appressoria }\end{array} \\ \text { Control }\left(\mathrm{H}_{2} \mathrm{O}\right) & 16 \pm 2 & 14 \pm 2 & 13 \pm 1 \\ \mathrm{SA} & 37 \pm 3 & 26 \pm 2 & 25 \pm 4 \\ \text { Glucose } & 12 \pm 2 & 11 \pm 1 & 10 \pm 2 \\ \text { Glutamine } & 37 \pm 4 & 18 \pm 2 & 14 \pm 2 \\ \text { Alanine } & 28 \pm 3 & 15 \pm 2 & 12 \pm 2\end{array}$

* All at a concentration of $5 \times 10^{-5} \mathrm{M}$.

significantly different between the $\mathrm{S}_{\mathrm{A}}$ and bacterial treatments, whilst in the presence of bacterial cells more of the appressoria were dark. Thus, although the percentage of total conidia that produced appressoria was lower in the bacterial treatment because of poorer germination, the percentage of conidia with dark appressoria did not differ significantly between $S_{A}$ and bacterial treatments. When considering the effect of a bacterial siderophore on $C$. acutatum conidia in a field situation, the stimulation of appressorium formation is particularly important since it is from these structures that the fungus penetrates and infects the host plant.

Germination was inhibited by $5 \times 10^{-5} \mathrm{M}-\mathrm{Fe}_{2}\left(\mathrm{SO}_{4}\right)_{3}$ and $\mathrm{S}_{\mathrm{A}} \mathrm{Fe}$, the fully chelated form of $\mathrm{S}_{\mathrm{A}}$ (Table 2). The failure of $S_{A} F e$ to stimulate germination reinforces the view that the biological effect of $S_{A}$ results from its capacity to bind iron. Few appressoria of any kind were produced in the presence of free $\mathrm{Fe}^{3+}$ and even fewer in $\mathrm{S}_{\mathrm{A}} \mathrm{Fe}$. That the relatively small number of appresoria which were produced in the presence of iron were predominantly hyaline is in accord with results obtained with $C$. musae (Swinburne \& Brown, 1983).

$\mathrm{S}_{\mathrm{A}}$ was compared with glucose, glutamine and alanine, each at concentrations of $5 \times 10^{-5} \mathrm{M}$ (Table 3). The amino acids significantly increased germination, glutamine to an extent 
Table 4. Effect of $S_{A}, S_{A} F e, \mathrm{Fe}^{3+}$, Pseudiomonas $U V 3$ and bacteria plus $\mathrm{Fe}^{3+}$ on the germination and appressorium formation by $C$. acutatum conidia on strawberry stolons

The results are means $\pm S E$.

\begin{tabular}{lcccc}
\multicolumn{1}{c}{ Treatment* } & $\begin{array}{c}\text { Percentage } \\
\text { germination }\end{array}$ & $\begin{array}{c}\text { Percentage of } \\
\text { all conidia } \\
\text { with appressoria }\end{array}$ & $\begin{array}{c}\text { Percentage of } \\
\text { appressoria } \\
\text { that were dark }\end{array}$ & $\begin{array}{c}\text { Percentage of } \\
\text { all conidia with } \\
\text { dark appressoria }\end{array}$ \\
Control $\left(\mathrm{H}_{2} \mathrm{O}\right)$ & $58 \pm 5$ & $38 \pm 4$ & $75 \pm 5$ & $28 \pm 4$ \\
$\mathrm{~S}_{\mathrm{A}}$ & $89 \pm 2$ & $78 \pm 3$ & $84 \pm 4$ & $66 \pm 4$ \\
$\mathrm{~S}_{\mathrm{A}} \mathrm{Fe}$ & $73 \pm 3$ & $37 \pm 3$ & $38 \pm 7$ & $13 \pm 3$ \\
$\mathrm{Fe}_{2}\left(\mathrm{SO}_{4}\right)_{3}$ & $50 \pm 6$ & $24 \pm 4$ & $35 \pm 8$ & $10 \pm 2$ \\
$P_{\text {seudomonas }}$ UV3 & $64 \pm 4$ & $47 \pm 4$ & $95 \pm 2$ & $44 \pm 4$ \\
Pseudomonas UV3+ $_{\mathrm{Fe}_{2}\left(\mathrm{SO}_{4}\right)_{3}}$ & $69 \pm 3$ & $55 \pm 4$ & $78 \pm 6$ & $43 \pm 5$
\end{tabular}

* $\mathrm{S}_{\mathrm{A}}, \mathrm{S}_{\mathrm{A}} \mathrm{Fe}$ and $\mathrm{Fe}_{2}\left(\mathrm{SO}_{4}\right)_{3}$ were added at a concentration of $5 \times 10^{-5} \mathrm{M}$. Bacteria were added at a concentration of $10^{7}$ cells $\mathrm{ml}^{-1}$.

comparable with $\mathrm{S}_{\mathrm{A}}$. However, this stimulation did not extend to appressorium formation. There was no significant difference in germination or appressorium formation between $5 \times 10^{-5} \mathrm{M}$-glucose and water. Blakeman \& Parbery (1977) used concentrations higher than those tested here and found that nutrients inhibit appressorium formation, and that germination in water was $100 \%$ and could not be stimulated. To simulate competition from bacteria they induced nutrient deprivation by leaching conidia between polycarbonate and cellulose acetate membranes. Such conidia germinated well and produced mostly dark appressoria. However, leaching may also have reduced the conidial iron content (or moved it from its site of action) which would have given rise to the observed effects in a way similar to that described here, and similar also to conidia grown under low-iron conditions (Graham \& Harper, 1983). However, nutrients must be involved in part since leaching with a nutrient solution, which, unless contaminated by iron, would also lower the iron content, does not stimulate appressorium formation. Excess exogenous nutrients induce saprophytic growth with conidia producing long ramifying germ tubes and few appressoria (Van Burgh, 1950; Skoropad, 1967). Although some micro-organisms may be able to utilize siderophores as a nutrient source, the stimulation of $C$. acutatum by $\mathrm{S}_{\mathrm{A}}$ cannot be wholly explained on a nutritional basis. The stimulatory effect of $\mathrm{S}_{\mathrm{A}}$ on germination and appressorium formation is much greater than that exhibited by equivalent concentrations of the nutrients tested.

\section{Germination and appressorium formation by C. acutatum conidia in vivo}

Percentage germination was significantly higher on strawberry stolons than on glass slides. $S_{A}$ had a marked stimulatory effect on germination but $S_{A} F e$ was not inhibitory (Table 4 ). The stimulation of germination by cells of isolate UV3 was diminished compared with the situation in vitro, resulting from a higher control value rather than a lowered efficacy of the bacterial treatment. Free $\mathrm{Fe}^{3+}$ in the inoculum drop had no significant effect on germination in either the presence or absence of added bacteria. The absence in vivo of the inhibitory action of free iron in vitro is not readily explained, but may be related to the complex interaction of factors on the stolon surface which may have buffered the effect of the iron.

$\mathrm{S}_{\mathrm{A}}$ increased the percentage of conidia. which formed appressoria (light plus dark), but the $S_{A} F e$ was not inhibitory, although it had none of the stimulatory effects of $S_{A}$ alone. The lack of inhibition by $\mathrm{S}_{\mathrm{A}} \mathrm{Fe}$ also differed from the situation in vitro and must be related to factors on the plant surface. Free $\mathrm{Fe}^{3+}$ reduced the number of appressoria formed, and Pseudomonas UV3 slightly increased it, but addition of iron to the bacteria had no effect on the stimulatory properties of the latter. $\mathrm{S}_{\mathrm{A}} \mathrm{Fe}$ and $\mathrm{Fe}^{3+}$ markedly reduced the percentage of dark appressoria produced by germinating conidia, while $S_{A}$ and isolate UV3 stimulated their formation compared with the control. The proportion of appressoria that were dark was significantly lowered by $S_{A} F e$ and $\mathrm{Fe}^{3+}$ and raised by the $S_{A}$ and isolate UV3 treatments, but there was no 
significant difference between the water control and the bacteria with iron. The total number of conidia which produced dark appressoria in vivo was stimulated by $\mathrm{S}_{\mathrm{A}}$ and inhibited by $\mathrm{S}_{\mathrm{A}} \mathrm{Fe}$ and by free $\mathrm{Fe}^{3+}$. Pseudomonas UV3 in water and in $\mathrm{Fe}^{3+}$ increased the number of dark appressoria but significantly less than did $\mathrm{S}_{\mathrm{A}}$. In general, the biological effects of free $\mathrm{Fe}^{3+}$ are more thoroughly reversed by the addition of live bacteria than by $S_{A}$. Blakeman \& Brodie (1977) showed that appressorium formation by Colletotrichum dematium $\mathrm{f}$. $\mathrm{sp}$. spiniciae on beetroot leaves was stimulated by Pseudomonas sp. isolate 14 while germination was unaffected. Although this is similar to the observed effect of Pseudomonas UV3 on C. acutatum it was attributed to nutrient competition. Pseudomonas 14 is also a siderophore-producing isolate (unpublished data) and it is probable that siderophores are involved in fungal infection processes.

A single factor operating alone is unlikely to be the sole determinant of germination and appressorium formation in vivo; rather, a number of different effects interacting at the plant surface are likely to influence the development of a fungal propagule landing on the phytoplane. A variety of factors can influence Colletotrichum spp., including temperature, light intensity, relative humidity, surface wetness, thigmotropic effects, spore age, nutrient status and host susceptibility (Emmett \& Parbery, 1975). The results reported in this study and by Swinburne (1981) add iron and siderophores to this list. The greater germination of $C$. acutatum in vivo than in vitro is not readily explained without further study but some of the factors outlined above may be involved in the complex interaction on the stolon surface and be absent from the germination assays on glass slides. Perhaps the most important feature of the effect of $\mathrm{S}_{\mathrm{A}}$ on $C$. acutatum in vivo is the stimulation of the formation of dark appressoria, the proportional occurrence of which is a critical factor in determining the success of $C$. musae infection of banana, a related anthracnose disease (Swinburne, 1976; Swinburne \& Brown, 1983).

The stimulation of germination and appressorium formation of $C$. acutatum by the bacterial siderophore $S_{A}$ heightens the importance of the role of phytoplane micro-organisms and their products in the complex relationship between a fungal pathogen and its host. It also indicates that the previously observed stimulation of fungal germination and appressorium formation by certain bacteria may be mediated, at least in part, by siderophores.

The assistance and advice of Dr R. Hignett is gratefully acknowledged. The work was supported by a grant from the Agricultural and Food Research Council, and carried out under MAFF licence no. PHF 212/202 issued under the Plant Pests (Great Britain) Order 1980.

\section{REFERENCES}

Adikaram, N. K. B., Brown, A. E. \& Swinburne, T. R. (1982). Rotting of immature Capsicum frutescens L. fruit by iron-depleted Glomerella cingulata (Stonem.). Physiological Plant Pathology 21, 171-177.

Blakeman, J. P. \& Brodie, I. D. S. (1977). Competition for nutrients between epiphytic microorganisms and germination of spores of plant pathogens on beetroot leaves. Physiological Plant Pathology 10, 2942.

Blakeman, J. P. \& Parbery, D. G. (1977). Stimulation of appressorium formation in Colletotrichum acutatum by phylloplane bacteria. Physiological Plant Pathology 11, 313-325.

Brodie, I. D. S. \& Blakeman, J. P. (1976). Competition for exogenous substances in vitro by leaf surface microorganisms and germination of conidia of Botrytis cinerea. Physiological Plant Pathology 9, 227239.

Brown, A. E. \& Swinburne, T. R. (1981). Influence of iron and iron chelates on formation of progressive lesions by Colletotrichum musae on banana fruits. Transactions of the British Mycological Society 77, 119-124.
Brown, A. E. \& Swinburne, T. R. (1982). Ironchelating agents and lesion development by Botrytis cinerea on leaves of Vicia faba. Physiological Plant Pathology 21, 13-21.

Emmett, R. \& Parbery, D. G. (1975). Appressoria. Annual Review of Phytopathology 13, 147-167.

Graham, A. H. \& HARPER, D. B. (1983). Distribution and transport of iron in conidia of Colletotrichum musae in relation to the mode of action of germination stimulants. Journal of General Microbiology 129, 1025-1034.

KING, E. O., WARD, M. K. \& RANEY, D. E. (1954). Two simple media for the demonstration of pyocyanin and fluorescin. Journal of Laboratory and Clinical Medicine 44, 301-307.

McCracken, A. R. \& Swinburne, T. R. (1979). Siderophores produced by saprophytic bacteria as stimulants of germination of conidia of Colletotrichum musae. Physiological Plant Pathology 15, 331340.

Meyer, J. M. \& Abdallah, M. A. (1978). The fluorescent pigment of Pseudomonas fluorescens: biosynthesis, purification and physicochemical pro- 
perties. Journal of General Microbiology 107, 319328.

MEYER, J. M. \& HornSPERger, J. M. (1978). Role of pyoverdine $_{\mathrm{Pi}}$, the iron-binding fluorescent pigment of Pseudomonas fluorescens, in iron transport. Journal of General Microbiology 107, 329-331.

SKoropad, W. P. (1967). Effect of temperature on the ability of Colletotrichum graminicola to form appressoria and penetrate barley leaves. Canadian Journal of Plant Science 47, 431-434.

SwinbURNE, T. R. (1976). Stimulants of germination and appressoria formation by Colletotrichum musae (Berk. \& Curt) Arx. in banana leachate. Phytoparhologische Zeitschrift 87, 74-90.

Swinburne, T. R. (1981). Iron and iron chelating agents as factors in germination, infection and aggression of fungal pathogens. In Microbial Ecology of the Phylloplane, pp. 227-243. Edited by J. P. Blakeman. London: Academic Press.
Swinburne, T. R. \& Brown, A. E. (1983). Appressoria development and quiescent infections of banana fruit by Colletotrichum musae. Transactions of the British Mycological Society 80, 176-178.

Tientze, M. \& LeONG, J. (1981). Structure of pseudobactin $A$, a 2 nd siderophore from plant growth promoting Pseudomonas B10. Biochemistry 20, 6457 6462.

Tientze, M., Hossain, M. B., Barnes, C. L., Leong, J. \& VAN DER HELM, D. (1981). Structure of ferric pseudobactin, a siderophore from a plant growth promoting Pseudomonas. Biochemistry 20, 64466457.

VAN BURGH, P. (1950). Some factors affecting appressorium formation and penetrability of Colletotrichum phomoides. (Abstract.) Phytopathology 40, 29. 